\title{
PENGELOLAAN LINEN RUMAH SAKIT DAERAH dr. ADNAAN WD PAYAKUMBUH SUMATERA BARAT
}

\author{
Darwel $^{1}$, Desyanti Adams ${ }^{2}$, Rahmi Hidayanti ${ }^{1}$ \\ ${ }^{1)}$ Jurusan Kesehatan Lingkungan, Poltekkes Kemenkes Padang, Jl. Simpang Pondok Kopi Siteba Padang \\ ${ }^{2)}$ RSUD dr. Adnaan WD Payakumbuh, Sumatera Barat \\ Email : wel_piero@yahoo.com
}

Submitted: 16-01-2019, Reviewer: 08-03-2019, Accepted: 24-07-2019

\begin{abstract}
The organization of environmental health of the hospital is carried out according to the environmental health requirements of the hospital. One of the supporting factors for hospitals in restoring patient health is the provision of linen. Regional General Hospital Dr. Adnaan WD Payakumbuh is a type $C$ regional hospital. Linen infectious and non-infectious patients used expatients or former health service activities are produced every day and no sorting of infectious and non-infectious linen is not done. Washing linen uses 1 washing machine to wash all types of linen, does not have a linen carriage storage room, coordination of linen staff with other parts, especially in repairing facilities and equipment is not optimal, linen managers still do not use personal protective equipment (PPE). This study aims to determine the description of linen management at Adnaan WD Payakumbuh Hospital. The research is descriptive with an observation approach. The research instrument used a checklist and measurements referring to the Kepmenkes RI No 1204 in 2004. The data were analyzed descriptively in the form of tables and percentages. The results of the 80\% linen washout, 100\% linen collection stage, 100\% transportation stage, $100 \%$ acceptance stage, $100 \%$ washing stage, $80 \%$ storage stage, and $100 \%$ distribution stage fulfilled the requirements.
\end{abstract}

Keywords: infection, non-infection, linen, hospital

\begin{abstract}
ABSTRAK
Penyelenggaraan kesehatan lingkungan rumah sakit dilakukan sesuai persyaratan kesehatan lingkungan rumah sakit. Salah satu faktor pendukung rumah sakit dalam pemulihan kesehatan pasien adalah penyediaan linen. Rumah Sakit Umum Daerah dr.Adnaan WD Payakumbuh merupakan rumah sakit daerah tipe C. Linen kotor infeksius dan non infeksius bekas pemakaian pasien atau bekas kegiatan pelayanan kesehatan dihasilkan tiap hari dan tidak dilakukan pemilahan antara linen infeksius dan non infeksius. Pencucian linen menggunakan 1 mesin cuci untuk mencuci semua jenis linen, tidak memiliki ruang tempat penyimpanan kereta linen, koordinasi petugas linen dengan bagian-bagian lain khususnya dalam perbaikan sarana dan peralatan belum optimal, pengelola linen masih ada yang tidak menggunakan alat pelindung diri (APD). Penelitian ini bertujuan mengetahui gambaran pengelolaan linen di RSUD Adnaan WD Payakumbuh. Penelitian bersifat deskriptif dengan pendekatan observasi. Instrument penelitian menggunakan checklist dan pengukuran mengacu kepada Kepmenkes RI No 1204 tahun 2004. Data di analisa secara deskriptif dalam bentuk tabel dan persentase. Hasil penelitian tempat pencucian linen sebesar $80 \%$, tahap pengumpulan linen $100 \%$, tahap pengangkutan $100 \%$, tahap penerimaan $100 \%$, tahap pencucian $100 \%$, tahap penyimpanan $80 \%$, dan tahap pendistribusian $100 \%$ memenuhi syarat.
\end{abstract}

Kata kunci : infeksi, non infeksi, linen, rumah sakit 


\section{PENDAHULUAN}

Pembangunan kesehatan adalah upaya yang bertujuan meningkatkan kesadaran, kemauan dan kemampuan hidup sehat untuk mewujudkan derajat kesehatan masyarakat yang setinggi-tingginya sebagai investasi pembangunan sumber daya manusia yang produktif secara sosial dan ekonomis (1). Kesehatan merupakan unsur kesejahteraan umum harus diwujudkan melalui upaya kesehatan dalam rangka pembangunan kesehatan secara menyeluruh dan terpadu yang didukung oleh suatu sistem kesehatan nasional (2).

Rumah sakit merupakan institusi kesehatan dimana sekelompok orang dengan berbagai disiplin ilmu dan keahlian melakukan aktifitas secara bersama dengan kegiatan utama pelayanan kesehatan yang bersifat preventif, kuratif, promotif dan rehablitatif (2).

Rumah sakit sebagai sarana pelayanan kesehatan tempat berkumpulnya orang sakit atau sehat, dapat menjadi tempat penularan penyakit serta memungkinkan terjadinya pencemaran lingkungan dan gangguan kesehatan. Penyelenggaraan kesehatan lingkungan rumah sakit perlu dilakukan sesuai dengan persyaratan kesehatan lingkungan rumah sakit (3).

Keberhasilan rumah sakit dalam menyediakan layanan kesehatan bagi masyarakat tidak hanya ditentukan oleh penyediaan sarana medik dan pelayanan medik. Faktor pendukung juga sangat menentukan keberhasilan rumah sakit dalam mempercepat pemulihan kesehatan pasien rumah sakit. Salah satu faktor pendukung tersebut adalah penyediaan linen (4).

Linen adalah serat lena yang didapat dari sejenis alang-alang yang tumbuh di daerah sub tropis yang dipintal dan ditenun menjadi tekstil halus dan berdaya serap tinggi. Pengelolaan linen tidak baik mempunyai dampak resiko penularan penyakit infeksi dan resiko bahaya yang akan mempengaruhi situasi dan kondisi di rumah sakit (5). Kebutuhan linen di setiap ruangan rumah sakit bervariasi baik jenis, jumlah dan kondisinya. Alur pengelolaan linen cukup panjang, membutuhkan pengelolaan khusus dan melibatkan banyak tenaga kesehatan. Kualitas linen yang baik penting diperhatikan agar terhindar dari penyakit infeksi dan efek penggunaan bahan (6).

Kendala yang sering ditemui dalam pengelolaan linen di rumah sakit seperti kualitas linen yang tidak baik, kualitas hasil pencucian sulit menghilangkan noda berat seperti darah, bahan kimia. Unit-unit pengguna linen tidak melakukan pembasahan terhadap noda, ruangan tidak memisahkan linen kotor terinfeksi dengan linen kotor tidak terinfeksi serta kurang kurangnya pemahaman dan kemampuan dalam pengelolaan linen (6).

Rumah Sakit Umum Daerah dr.Adnaan WD Payakumbuh Sumatera Barat adalah salah satu rumah sakit daerah dengan kelas C. Sebagai salah satu rumah sakit, RSUD dr.Adnaan WD mempunyai potensi menyebabkan terjadinya infeksi nosokomial. Linen kotor infeksius dan non infeksius bekas pemakaian pasien atau bekas kegiatan pelayanan kesehatan selalu dihasilkan setiap hari. Hasil survey awal di RSUD Adnaan WD, tidak dilakukan pemilahan antara linen infeksius dan non infeksius. Pencucian linen menggunakan 1 mesin cuci untuk mencuci semua jenis linen, tidak memiliki ruang tempat penyimpanan kereta linen, koordinasi petugas linen dengan bagianbagian lain khususnya dalam perbaikan sarana dan peralatan belum optimal, pengelola linen masih ada yang tidak menggunakan alat pelindung diri (APD), sehingga dapat terjadi penyakit akibat kontak langsung antara linen terhadap petugas.

Penelitian ini bertujuan melihat gambaran pengelolaan linen di Rumah Sakit 
Umum Daerah dr. Adnaan WD Payakumbuh Sumatera Barat.

\section{METODE PENELITIAN}

Jenis penelitian ini bersifat deskriptif dengan pendekatan observasi untuk menggambarkan pengelolaan linen di Rumah Sakit Umum Daerah dr.Adnaan WD Payakumbuh Sumatera Barat. Objek penelitian adalah tempat pencucian linen, tempat pengumpulan linen, tempat pengangkutan linen, tempat penerimaan linen, pencucian linen, tempat penyimpanan linen, dan tempat pendistribusian linen. Instrumen penelitian adalah checklist dan pengukuran, mengacu pada Kepmenkes RI No.1204 tahun 2004 tentang persyaratan
Kesehatan Lingkungan Rumah Sakit. Analisis data dilakukan secara deskriptif dalam bentuk tabel dan persentase.

\section{HASIL DAN PEMBAHASAN}

RSUD dr. Adnaan WD Payakumbuh terletak di Jl. Ade Irma Suryani Nasution No.25 Balai Kaliki, Payakumbuh Sumatera Barat. Ruangan pengelolaan linen di Rumah Sakit Umum Daerah dr. Adnaan WD Payakumbuh memiliki luas bangunan $120 \mathrm{~m}^{2}$ terdiri dari kantor, ruangan penerimaan, gudang, ruangan pencucian dan pengeringan, ruangan penyetrikaan, ruangan penyimpanan dan pendistribusian, dan kamar mandi.

Tabel 1. Tempat Pencucian Linen RSUD dr. Adnan WD Payakumbuh Tahun 2018

\begin{tabular}{|c|c|c|c|c|}
\hline \multirow[b]{2}{*}{ No } & \multirow[b]{2}{*}{ Variabel } & \multicolumn{2}{|c|}{ Kriteria } & \multirow[b]{2}{*}{ Jumlah } \\
\hline & & $\mathrm{Ya}$ & Tidak & \\
\hline 1 & $\begin{array}{l}\text { Terdapat kran air bersih dengan kapasitas, kualitas, dan tekanan } \\
\text { yang memadai, disediakan kran air panas untuk desinfektan awal }\end{array}$ & $\sqrt{ }$ & & \\
\hline 2 & Dilakukan pemilahan antara linen infeksius dan non infeksius & $\sqrt{ }$ & & \\
\hline 3 & Tersedia ruangan yang terpisah antara linen bersih dan kotor & $\sqrt{ }$ & & \\
\hline 4 & $\begin{array}{l}\text { Lokasi mudah dijangkau dan jauh dari pasien serta tidak berada } \\
\text { dijalan }\end{array}$ & $\sqrt{ }$ & & \\
\hline 5 & $\begin{array}{l}\text { Lantai terbuat daribeton/plester yang kuat, rata, tidak licin, } \\
\text { dengan kemiringan }>2-3 \%\end{array}$ & $\sqrt{ }$ & & \\
\hline 6 & Ruangan pencucian linen infeksius \& non infeksius terpisah & & $\sqrt{ }$ & \\
\hline 7 & Pencahayaan $>200$ lux & & $\sqrt{ }$ & \\
\hline 8 & Kebisingan $78 \mathrm{~dB}$ & $\sqrt{ }$ & & \\
\hline 9 & Terdapat sarana pengering untuk alat-alat sehabis dicuci & $\sqrt{ }$ & & \\
\hline \multirow[t]{3}{*}{10} & Limbah disalurkan melalui saluran tertutup, kedap air, lancar & $\sqrt{ }$ & & \\
\hline & Skor & 8 & 2 & 10 \\
\hline & Persentase & 80 & 20 & 100 \\
\hline
\end{tabular}

Tabel 2. Pengelolaan Linen Tahap Pengumpulan di RSUD dr. Adnaan WD Payakumbuh 2018

\begin{tabular}{llccc}
\hline \multirow{2}{*}{ No } & \multicolumn{1}{c}{ Variabel } & \multicolumn{2}{c}{ Kriteria } & \multirow{2}{*}{ Jumlah } \\
\cline { 3 - 5 } & & Ya & Tidak \\
\hline 1 & Dilakukan pemilahan linen infeksius dan non infeksius & $\sqrt{ }$ & \\
2 & Linen dimasukkan ke kantong sesuai jenisnya dan di label & $\sqrt{ }$ & \\
3 & Menghitung dan mencatat linen & $\sqrt{ }$ & \\
4 & Dilakukan pemilihan tingkat kekotoran linen di laundry & $\sqrt{ }$ & \\
\hline & Skor & 4 & 0 & 4 \\
\hline & Persentase (\%) & 100 & 0 & 100 \\
\hline
\end{tabular}


Tabel 3 Pengelolaan Linen Tahap Pengangkutan Linen RSUD dr. Adnaan WD Payakumbuh

\begin{tabular}{|c|c|c|c|c|}
\hline \multirow[t]{2}{*}{ No } & \multirow[t]{2}{*}{ Variabel } & \multicolumn{2}{|c|}{ Kriteria } & \multirow[t]{2}{*}{ Jumlah } \\
\hline & & $\mathrm{Ya}$ & Tidak & \\
\hline 1 & $\begin{array}{l}\text { Kantong yang membungkus linen bersih dibedakan dengan } \\
\text { kantong yang membungkus linen kotor }\end{array}$ & $\sqrt{ }$ & & \\
\hline 2 & $\begin{array}{l}\text { Kereta dorong untuk linen bersih dan linen kotor berbeda dan } \\
\text { tertutup }\end{array}$ & $\sqrt{ }$ & & \\
\hline 3 & $\begin{array}{l}\text { Kereta dorong harus dicuci dengan desinfektan setelah } \\
\text { mengangkut linen kotor }\end{array}$ & $\sqrt{ }$ & & \\
\hline 4 & Waktu pengangkutan linen bersih dan linen kotor berbeda & $\sqrt{ }$ & & \\
\hline & Skor & 4 & 0 & 4 \\
\hline & Persentase $(\%)$ & 100 & 0 & 100 \\
\hline
\end{tabular}

Tabel 4. Pengelolaan Linen Tahap Penerimaan Linen RSUD dr. Adnaan WD Payakumbuh

\begin{tabular}{|c|c|c|c|c|}
\hline \multirow[t]{2}{*}{ No } & \multirow[t]{2}{*}{ Variabel } & \multicolumn{2}{|c|}{ Kriteria } & \multirow[t]{2}{*}{ Jumlah } \\
\hline & & $\mathrm{Ya}$ & Tidak & \\
\hline 1 & Mencatat linen yang diterima & $\sqrt{ }$ & & \\
\hline 2 & $\begin{array}{l}\text { Linen yang telah diterima dipisahkan antara linen infeksius dan } \\
\text { non infeksius }\end{array}$ & $\sqrt{ }$ & & \\
\hline 3 & Linen dipisahkan berdasarkan tingkat kekotoran & $\sqrt{ }$ & & \\
\hline & Skor & 3 & 0 & 3 \\
\hline & Persentase $(\%)$ & 100 & 0 & 100 \\
\hline
\end{tabular}

Tabel 5. Pengelolaan Linen Tahap Pencucian Linen RSUD dr. Adnaan WD Payakumbuh

\begin{tabular}{|c|c|c|c|c|}
\hline \multirow[t]{2}{*}{ No } & \multirow[t]{2}{*}{ Variabel } & \multicolumn{2}{|c|}{ Kriteria } & \multirow[t]{2}{*}{ Jumlah } \\
\hline & & $\mathrm{Ya}$ & Tidak & \\
\hline 1 & Dilakukan penimbangan berat linen terlebih dahulu & $\sqrt{ }$ & & \\
\hline 2 & $\begin{array}{l}\text { Sebelum pencucian dilakukan penyortiran terlebih dahulu dan tidak } \\
\text { diletakkan di lantai }\end{array}$ & $\sqrt{ }$ & & \\
\hline 3 & $\begin{array}{l}\text { Dilakukan pembersihan linen kotor dari tinja, urin darah, dan } \\
\text { muntahan }\end{array}$ & $\sqrt{ }$ & & \\
\hline 4 & $\begin{array}{l}\text { Dilakukan perendaman terhadap linen infeksius terlebih dahulu } \\
\text { menggunakan desinfektan }\end{array}$ & $\sqrt{ }$ & & \\
\hline 5 & $\begin{array}{l}\text { Proses desinfektan menggunakan suhu air panas } 70^{\circ} \mathrm{C} \\
\text { selama } 25 \text { menit atau } 95^{\circ} \mathrm{C} \text { selama } 10 \text { menit }\end{array}$ & $\sqrt{ }$ & & \\
\hline 6 & Pencucian dikelompokkan berdasarkan tingkat kekotorannya & $\sqrt{ }$ & & \\
\hline & Skor & 6 & 0 & 6 \\
\hline & Persentase & 100 & 0 & 100 \\
\hline
\end{tabular}

Tabel 6. Pengelolaan Linen Tahap Penyimpanan Linen Rumah Sakit Umum Daerah dr. Adnaan WD Payakumbuh Tahun 2018

\begin{tabular}{|c|c|c|c|c|}
\hline \multirow[t]{2}{*}{ No } & \multirow[t]{2}{*}{ Variabel } & \multicolumn{2}{|c|}{ Kriteria } & \multirow[t]{2}{*}{ Jumlah } \\
\hline & & Ya & Tidak & \\
\hline 1 & Dilakukan pemisahan linen sesuai dengan jenisnya & $\sqrt{ }$ & & \\
\hline 2 & Linen disimpan dilemari tertutup & $\sqrt{ }$ & & \\
\hline 3 & Linen dibungkus dengan plastik & & $\sqrt{ }$ & \\
\hline 4 & Pintu linen harus tertutup & $\sqrt{ }$ & & \\
\hline 5 & Ruang penyimpanan bersih, bebas debu dan tidak lembab & $\sqrt{ }$ & & \\
\hline & Skor & 4 & 1 & 5 \\
\hline & Persentase & 80 & 20 & 100 \\
\hline
\end{tabular}


Tabel 7 Pengelolaan Linen Tahap Pendistribusian Linen RSUD dr. Adnaan WD Payakumbuh

\begin{tabular}{llccc}
\hline & \multicolumn{1}{c}{ Variabel } & \multicolumn{2}{c}{ Kriteria } & Jumlah \\
\cline { 3 - 5 } No & & \multicolumn{2}{c}{ Ya } & \\
\hline 1 & Linen dalam keadaan tertutup dan terbungkus rapi saat di & $\sqrt{ }$ & \\
& bawa ke ruang perawatan & & \\
2 & Linen untuk ruang operasi harus di lakukan sterilisasi & $\sqrt{ }$ & \\
3 & Menggunakan trolli yang berbeda dengan trolli linen kotor & $\sqrt{ }$ & \\
4 & Trolley yang di gunakan tertutup & $\sqrt{ }$ & \\
5 & Dilakukan distribusi linen berdasarkan kartu tanda terima & $\sqrt{ }$ & \\
& dari petugas & & & \\
\hline & Skor & 5 & 0 & 5 \\
\hline & Persentase & 100 & 0 & 100 \\
\hline
\end{tabular}

\section{Tempat Pencucian Linen}

Tempat pencucian linen Rumah Sakit dr. Adnaan WD Payakumbuh memenuhi syarat kesehatan sebesar $80 \%$, sedangkan yang tidak memenuhi syarat kesehatan sebesar $20 \%$. Tempat pencucian linen ini telah memenuhi syarat sesuai Kepmenkes 1204 Tahun 2004 (skor $\geq 55 \%$ ) seperti pada tabel 1.

\section{Proses Pengelolaan Linen Pada Tahap Pengumpulan}

Proses pengelolaan linen pada tahap pengumpulan di Rumah Sakit dr. Adnaan WD Payakumbuh mempunyai nilai $100 \%$, artinya pengelolaan linen pada tahap pengumpulan di RSUD dr Adnaan WD Payakumbuh telah memenuhi syarat ( $\geq 55 \%)$, seperti pada tabel 2 .

\section{Proses Pengelolaan Linen Tahap pengangkutan}

Proses pengelolaan linen pada tahap pengangkutan linen di Rumah Sakit dr. Adnaan WD Payakumbuh sebesar $100 \%$, dinyatakan memenuhi syarat ( $\geq 55 \%$ sesuai Kepmenkes 1204 tahun 2004) seperti pada tabel 3.

\section{Proses Pengelolaan Linen Pada Tahap penerimaan}

Tahap penerimaan linen diperoleh skor $100 \%$, artinya pengelolaan linen
Rumah Sakit dr.Adnaan WD Payakumbuh pada tahap penerimaan telah memenuhi persyaratan sesuai Kepmenkes 1204 tahun 2004 ( $\geq 55 \%$ ) seperti pada tabel 4 .

\section{Proses Pengelolaan Linen Pada Tahap Pencucian}

Pengelolaan linen pada tahap pencucian linen diperoleh skor $100 \%$, artinya pengelolaan linen Rumah Sakit dr.Adnaan WD Payakumbuh pada tahap pencucian telah memenuhi persyaratan sesuai Kepmenkes 1204 tahun 2004 ( $\geq$ 55\%) seperti pada tabel 5.

\section{Proses Pengelolaan Linen Pada Tahap penyimpanan}

Pengelolaan linen pada tahap penyimpanan linen mempunyai $80 \%$, artinya pengelolaan linen Rumah Sakit dr.Adnaan WD Payakumbuh pada tahap penyimpanan telah memenuhi persyaratan sesuai Kepmenkes 1204 tahun 2004 ( $\geq 55 \%)$ seperti pada tabel 6 .

\section{Proses Pengelolaan Linen Pada Tahap pendistribusian}

Pengelolaan linen pada tahap pendistribusian linen diperoleh skor 100\%, artinya pengelolaan linen Rumah Sakit dr.Adnaan WD Payakumbuh pada tahap pencucian telah memenuhi persyaratan 
sesuai Kepmenkes 1204 tahun 2004 ( $\geq$ $55 \%$ ) seperti pada tabel 7.

\section{PEMBAHASAN}

\section{Tempat Pencucian Linen}

Tempat pencucian linen Rumah Sakit Umum Daerah dr. Adnaan WD Payakumbuh sesuai persyaratan kesehatan sebesar $80 \%$ dan tidak memenuhi syarat kesehatan sebesar 20\%. Ruang pencucian linen infeksius dan non infeksius tidak terpisah. Hasil pengukuran pencahayaan adalah 165.16 Lux.

Penelitian ini sejalan dengan Nungrahaningrum di RSUD Dr. Moewardi Surakarta. Ruang cuci tidak terpisah antara linen infeksius dan linen non infeksius, peralatan mesin cuci dipasang permanen untuk mencuci berbagai jenis linen. Hal ini dapat menyebabkan terjadinya infeksi silang linen non infeksi.

Linen harus disediakan dalam ruangruang terpisah sesuai kegunaannya yaitu ruang linen kotor, ruang linen bersih, ruang untuk perlengkapan kebersihan, ruang perlengkapan cuci, ruang kereta linen, kamar mandi, dan ruang pengerin untuk alat-alat (7).

Pengukuran pencahayaan tempat pencucian linen adalah 165,16 Lux. Hasil ini tidak sesuai dengan Kepmenkes 1204 Tahun 2004 tentang Persyaratan Kesehatan Lingkungan Rumah Sakit, bahwa pencahayaan ruang tempat pencucian > 200 Lux. Pencahayaan yang tidak memenuhi syarat dapat mengganggu kualitas pekerja dalam pelaksanaan laundry. Pencahayaan pada tempat pencucian linen dapat ditingkatkan dengan menambahkan sumber pencahayaan, baik secara alami atau buatan.

Diharapkan kepada pihak Rumah Sakit untuk dapat memisahkan ruang tempat pencucian linen infeksius dengan ruang tempat pencucian linen non infeksius. Rumah Sakit sebaiknya menambah sumber pencahayaan diruangan pencucian agar pelaksanaan pencucian linen dapat berjalan sebagaimana mestinya.

\section{Proses Pengumpulan.}

Pengelolaan linen pada tahap pengumpulan sudah memenuhi persyaratan kesehatan dengan nilai sebesar $100 \%$. Tahap pengumpulan linen melakukan pemisahan linen infeksius dan linen non infeksius, linen yang akan dibawa dicatat dan dihitung sebelum diangkut keruang laundry agar tidak ada terjadi kekurangan atau kesalahan pada saat pengantaran kembali.

Pemilahan antara linen infeksius dan non-infeksius dimulai dari sumber dan memasukkan linen ke dalam kantong plastik sesuai jenisnya, serta diangkut dengan menggunakan kereta dorong yang berbeda dan tertutup antara linen bersih dan linen kotor(7).

Linen bekas pasien yang menderita penyakit menular langsung dipisahkan dan dimasukkan kedalam kantong agar tidak tercemar dengan linen yang lain. Pemilahan linen diruang laundry dilakukan berdasarkan tingkat kekotoran agar mudah dicuci (8).

\section{Proses Pengangkutan}

Pengelolaan linen pada tahap pengangkutan telah memenuhi persyaratan kesehatan dengan nilai sebesar $100 \%$. Pengangkutan linen bersih dan linen kotor diangkut dengan troli yang berbeda dan tertutup, kereta dorong dicuci menggunakan desinfektan setelah mengangkut linen kotor dan waktu pengangkutan linen kotor dan linen bersih berbeda.

Pengangkutan linen bersih dan kotor tidak boleh pada waktu yang bersamaan. Linen bersih diangkut dengan kereta dorong yang berbeda warna. Bila rumah sakit tidak mempunyai laundry tersendiri 
maka pengankutan dari dan ke tempat londri harus menggunakan mobil khusus. Petugas yang bekerja menggunakan pakaian kerja khusus, alat pelindung diri dan dilakukan pemeriksaan secara berkala (4).

Kontainer dan kereta yang digunakan untuk mengantar linen bersih dan kotor harus dipasang label. Penggunaan troli yang sama memungkinkan terjadinya infeksi hal ini disebabkan oleh penggunaan alat yang terkontaminasi. Troli bagian dalam harus dilapisi plastik dan setelah digunakan troli harus dibersihkan dan dalam keadaan tertutup.

Hasil observasi tahap pengangkutan linen di Instalasi laundry RSUD dr. Adnaan WD Payakumbuh diperoleh skor $100 \%$, bila dibandingkan dengan persyaratan nilai minimum Kepmenkes No. 1204 tahun 2004 skor $55 \%$, maka dapat dinyatakan tahapan pengangkutan linen telah memenuhi syarat.

\section{Proses Penerimaan}

Tahap penerimaan linen di RSUD dr. Adnaan WD Payakumbuh dinyatakan memenuhi syarat dengan skor sebesar $100 \%$. Linen yang telah diterima dan masuk dicatat, sehingga dapat dilakukan pengecekan sebelum pengangkutan ke ruang masing-masing. Linen yang diterima telah dipisahkan antara linen infeksius dan non infeksius, serta dipisahkan berdasarkan tingkat kekotorannya.

Hasil penelitian ini sejalan dengan Riansyah (2013) tentang pengelolaan linen di Rumah Sakit Siti Rahmah Padang bahwa linen bekas pakaian pasien HIV, persalinan, dipisahkan dan dimasukkan dalam kantong plastik agar tidak tercampur dengan linen yang lain.

Hasil pengamatan pada tahap penerimaan di instalasi laundry RSUD dr. Adnaan WD Payakumbuh, diperoleh skor
100\%, bila dibandingkan dengan persyaratan nilai minimum Kepmenkes 1204 tahun 2004 tentang Persyaratan Kesehatan Lingkungan dinyatakan telah memenuhi syarat (skor minimum 55\%).

\section{Proses Pencucian}

Tahap pencucian linen di Rumah Sakit Umum Daerah dr. Adnaan WD Payakumbuh memperoleh skor nilai $100 \%$. Penimbangan berat linen dilakukan sebelum dicuci, telah disortir dan tidak diletakkan di lantai, melakukan pembersihan linen kotor dari tinja, urin, darah, dan muntahan; melakukan perendaman terhadap linen infeksius dengan menggunakan desinfektan air panas bersuhu $70^{0} \mathrm{C}$ selama 25 menit atau dengan suhu $95^{\circ} \mathrm{C}$ selama 10 menit dan pencucian linen dikelompokkan berdasarkan tingkat kekotorannya.

Pada tahapan pencucian linen harus dilakukan penimbangan berat linen untuk menyesuaikan dengan kapasitas mesin cuci dan kebutuhan detergen (7). Proses pencucian dapat menggunakan tangan atau mesin cuci . Suhu dan siklus waktu dalam pencucian harus disesuaikan serta bahan kimia pembersih yang digunakan sesuai dengan petunjuk yang tertera dalam mesin cuci (9).

Hasil pengamatan pada tahap pencucian linen yang dilakukan di Instalasi laundry RSUD dr.Adnaan WD Payakumbuh dengan skor $100 \%$ dinyatakan memenuhi syarat sesuai Kepmenkes 1204 tahun 2004 tentang pesryaratan kesehatan lingkungan dengan skor 55\%. Namun para petugas yang bekerja tidak menggunakan baju kerja sehingga disarankan kepada pihak Rumah Sakit menyediakan baju kerja agar terhindar kontak langsung dengan linen kotor yang dapat menularkan penyakit. 


\section{Proses Penyimpanan}

Hasil penilaian terhadap pengelolaan linen pad atahap penyimpanan di peroleh skor nilai $80 \%$ telah memenuhi syarat dan $20 \%$ belum memenuhi syarat. Penyimpanan linen sesuai dengan jenisnya, diletakkan di lemari tertutup, pintu penyimpanan tertutup, ruang pemnyimpanan bersih bebas bau dan tidak lembab. Namun penyimpanan linen tidak dibungkus dengan plastik.

Penyimpanan mempunyai tujuan melindungi linen dari kontaminasi ulang serta mengontrol posisi linen tetap stabil. Lemari penyimpanan dipisahkan menurut masing-masing ruangan dan diberi obat anti ngengat seperti kapur barus (6). Penyimpanan linen harus dipisah sesuai jenisnya. Linen baru diterima ditempatkan dibagian bawah dan pintu lemari selalu tertutup (10).

Penyimpanan linen yang belum terpisah antara linen bersih dengan linen kotor dapat menjadi tempat hidup dan berkembangnya mikroorganisme seperti virus dan bakteri (11).

Tahap penyimpanan linen di rumah sakit dr. Adnaan WD Payakumbuh tidak menggunakan plastik untuk membungkus linen yang sudah bersih, hal ini dapat menyebabkan terjadinya kontaminasi oleh virus atau bakteri. Sehingga di sarankan agar penyimpanan linen menggunakan plastik pembungkus.

\section{Proses Pendistribusian}

Tahap pendistribusian linen berdasarkan observasi memperoleh skor $100 \%$. Tahap pendistribusian linen dilakukan dalam keadaan tertutup menggunakan troli yang berbeda antara linen bersih dan linen kotor. Trolli yang digunakan dalam keadaan tertutup, sehingga resiko kontak pencemaran linen bersih oleh berbagai macam mikroorganisme tidak tercemar. Linen ruang operasi terlebih dahulu disterilkan di ruang sterilisasi. Linen didistribusikan berdasarkan kartu tanda terima dari petugas.

Linen bersih diangkut dengan kereta dorong yang berbeda warna. Waktu pengangkutan linen bersih dan linen kotor tidak boleh dilakukan bersamaan waktunya dan tidak boleh disatukan dalam satu kereta dorong, harus dipisahkan antara linen bersih dan linen kotor (7).

Petugas yang mendistribusikan linen bersih dan pengumpul linen kotor sebaiknya dibedakan. Pendistribusian linen tidak terbungkus rapid an menggunakan plastic transparan dapat menyebabkan kontaminasi dari udara luar dan menurunkan kualitas linen (6).

Pendistribusian linen pada RSUD dr. Adnaan WD Payakumbuh telah memenuhi persyaratan kesehatan karena telah melebihi persyaratan yang ditetapkan sesuai Kepmenkes No. 1204 tahun 2004 tentang Persyaratan Kesehatan Lingkungan Rumah Sakit (55\%)

\section{SIMPULAN}

Pengelolaan linen pada RSUD dr. Adnaan WD Payalumbuh pada tempat pencucian, tahap pengumpulan, pengangkutan, penerimaan, pencucian, penyimpanan dan pendistribusian linen telah memenuhi persyaratan kesehatan dengan nilai di atas persyaratan minimum sesuai Kepmenkes No 1204 Tahun 2004 ( $\geq$ 55\%).

\section{REFERENSI}

Kemenkes RI. Rencana Strategis Kementerian Kesehatan Tahun 20152019 [Internet]. Kementerian Kesehatan RI. 2015. p. 248. Available from: http://www.depkes.go.id/resources/dow nload/info-publik/Renstra-2015.pdf

Undang Undang Republik Indonesia Nomor 44 Tahun 2009 Tentang Rumah Sakit. 2009.

Kemenkes RI. Keputusan Menteri Kesehatan No.1204/Menkes/SK/X/2004 
tentang Persyaratan Kesehatan Lingkungan RS. Jakarta: Kementrian Kesehatan; 2004.

Kusrini W, Dindin W. Sanitasi Rumah Sakit. Pertama. Pusat Pendidikan Sumber Daya Manusia Kesehatan. Badan Pengembangan dan Pemberdayaan Sumber Daya Manusia Kesehatan Edisi Tahun 2018. Jakarta; 2018. 223 p.

Prasetyo Yd. Studi Sanitasi Pengelolaan Linen Di Rumah Sakit Pku Muhammadiyah Gombong Kabupaten Kebumen Tahun 2015. 2015;

Zulkifli. Gambaran Pengeloalan Linen Di Rumah Sakit Umum Yarsi Pontianak. Gambaran Pengelolaan Linen Di
Rumah Sakit Umum Yars Pontianak. 2016;

Boy Subirosa. Manajemen Rumah Sakit. 2009.

Annisa Sri Wahyuni. Gambaran Pengelolaan Linen di rumah Sakit Umum Daerah Pariaman Tahun 2016. 2016.

Hingawati Setio. Panduan Praktek Keperawatan. Yogyakarta: Citra Aji Parama; 2010.

Manajemen P. Pedoman Manajemen Linen di Rumah Sakit. 2004;

Riansyah Rici. Gambaran Pengelolaan Linen Di Rumah Sakit Islam Siti Rahmah Padang Tahun 2017. Padang; 2017. 